\title{
Penerapan Media Pembelajaran Berbasis Software Wondershare Filmora pada Mata Pelajaran IPA di SD
}

\author{
Fenny Ramadhayanti ${ }^{1)^{*},}$ Mustamiroh ${ }^{2)}$ \\ ${ }^{1)}$ Program Studi Pendidikan Guru Sekolah Dasar, Universitas Mulawarman \\ *fennyram18@gmail.com
}

Abstrak: Penelitian ini dilatarbelakangi oleh seorang guru diharapkan memiliki kecakapan dalam melaksanakan kegiatan proses belajar mengajar, ketepatan memilih metode dan model pembelajaran serta pemilihan media pembelajaran agar kegiatan belajar mengajar efektif dan menyenangkan. Tujuan penelitian ini adalah untuk menjelaskan penerapan media pembelajaran dan dampak dari penerapan media pembelajaran berbasis software wondershare filmora mata pelajaran IPA di kelas VI SD. Jenis penelitian ini adalah kualitatif deskriptif. Teknik Pengumpulan data menggunakan wawancara, observasi, dan dokumentasi. Teknik analisis data dilakukan dengan mereduksi data, menyajikan data, dan menarik kesimpulan. Subjek penelitian atau sumber data adalah guru kelas dan siswa VI SD Negeri 006 Balikpapan. Hasil penelitian menunjukkan penerapan media pembelajaran berbasis software wondershare filmora memberikan dampak yang baik. Kegiatan pelaksanaan yang dilakukan yaitu menyusun RPP, menyusun materi sesuai $\mathrm{KD}$, merekam diri, mengedit video, dan mempublikasikan melalui youtube. Dampak yang terjadi dalam menerapkan media pembelajaran ini adalah dampak positif dengan nilai hasil pembelajaran beberapa siswa yang sebelum menggunakan media dan sesudah menggunakan media pembelajaran, dapat dibuktikan dengan nilai rata-rata sebesar 77,15 dari yang sebelumnya nilai 60. Kesimpulan dari penelitian ini menunjukkan bahwa penerapan media pembelajaran berbasis software wondershare filmora pada mata pelajaran IPA, siswa menjadi lebih paham, tidak jenuh dalam kegiatan pembelajaran serta meningkatkan hasil belajar.

Kata Kunci: Penerapan Media Pembelajaran, Software Wondershare Filmora, Mata Pelajaran IPA

\section{PENDAHULUAN}

Pendidikan merupakan hal penting yang harus dijalani oleh setiap manusia. Setiap warga negara Indonesia berhak mendapatkan ilmu dari sekolah. Guru adalah salah satu hal penting yang terdapat dalam Pendidikan, tanpa guru ilmu Pendidikan tidak dapat disampaikan dengan baik dan terarah. (Wahid, 2018) guru sebagai salah satu komponen dalam kegiatan pembelajaran memiliki posisi yang sangat menentukan keberhasilan pembelajaran. Sejalan dengan pendapat yang dikemukakan oleh (sugiyono, 2017) guru yang melakukan pembelajaran di kelas akan menemui sebuah permasalahan ataupun kendala seperti halnya konsentrasi siswa. Konsentrasi siswa biasanya dalam pembelajaran hanya berpusat lima belas menit pada awal pembelajaran, kemudian media yang digunakan guru juga kurang bervariatif sehingga hal tersebut dapat mempengaruhi kejenuhan siswa dalam mengikuti pembelajaran dikelas, sehingga hal tersebut memiliki dampak pada pencapaian tujuan pembelajaran yang kurang optimal. Guru saat ini tidak lagi sebagai penyalur sumber ilmu atau fasilitator yang hanya menyajikan materi yang berbasis buku. Guru diharapkan memiliki kecakapan dalam melaksanakan kegiatan proses belajar mengajar, ketepatan memilih metode dan model pembelajaran serta pemilihan media pembelajaran agar kegiatan belajar mengajar efektif dan menyenangkan. Hal ini, guru perlu didukung dengan adanya sarana dan prasarana yang memadai. Kemajuan dalam bidang teknologi informasi dan komunikasi dapat dimanfaatkan dalam dunia Pendidikan, banyak alternatif pembelajaran yang bisa dimunculkan dari pemanfaatan teknologi (Bouato et al., 2020).

Penggunaan teknologi pada saat ini sangat dibutuhkan untuk menunjang kualitas dari pendidikan. Hal ini seperti yang diungkapkan oleh (Lestari, 2018) teknologi merupakan hasil dari perkembangan ilmu pengetahuan, yang terjadi di dunia pendidkan. Oleh karena itu sudah selayaknya pendidikan juga memanfaatkan teknologi untuk membantu pelaksanaan pembelajaran. Hal tersebut juga sejalan dengan pendapat (Tea, 2019) 
teknologi berpengaruh besar terhadap orang banyak secara luas dan terkhususnya pada peserta didik. Teknologi telah menciptakan sebuah bentuk pengaruh berupa efek yang menjurus pada lingkup pendidikan, hal tersebut dapat merubah cara mengajar dan belajar serta cara berpikir peserta didik. Media pembelajaran dapat dibuat dengan kemajuan teknologi yang ada dan dapat mempermudah proses pekerjaan guru dan juga melatih peserta didik untuk lebih paham. (sugiyono, 2017) mengemukakan bahwa media pembelajaran merupakan bagian dari proses belajar mengajar. Hal tersebut sejalan dengan pendapat (Rosyid, 2019) menyatakan bahwa, media pembelajaran dimanfaatkan untuk menunjang tujuan dalam proses belajar mengajar di kelas salah satu media pembelajaran yang mudah digunakan oleh guru adalah software wondershare filmora.

Software wondershare filmora tersebut pada dasarnya adalah sebuah program yang dirancang untuk mengedit video dengan mudah dan sederhana dan memiliki kualitas yang sangat powerfull. (Isroqmi, 2015) berpendapat bahwa software dapat diartikan sebagai susunan data-data digital yang telah didesain, disusun, didefinisikan, dan disimpan kedalam suatu media sesuai dengan bahasa mesin, agar dapat dipergunakan untuk menterjemahkan perintah atau eksekusi-eksekusi yang diinginkan. (Nurpavitra \& Sudjanarti, 2019) menjelaskan bahwa wondershare filmora merupakan salah satu dari sekian banyak dari editor video yang berkembang di seluruh dunia. (Kurniawan, 2020) mengemukakan ada beberapa kelebihan wondershare filmora yaitu aplikasinya sangat ringan, pengoperasiannya sangat mudah, proses editing bisa lebih cepat, dan banyak efek yang tersedia serta menarik untuk dilakukan. Video pembelajaran yang dibuat dengan aplikasi wondershare filmora ini dapat digunakan oleh siswa dalam pembelajaran secara mandiri maupun berkelompok, di sekolah maupun di rumah, dan di manapun mereka berada nantinya (Eliwatis \& Sabarullah, 2021). Dalam pelaksanaan pembelajaran, guru telah memanfaatkan fasilitas grup pada aplikasi WhatsApp, penyampaian materi menggunakan buku elektronik berbentuk pdf, dan setiap seminggu sekali menggunakan zoom clouds meeting agar terciptanya komunikasi dua arah antara guru dan siswa. Penyajian materi yang hanya memberikan soal pada buku elektronik seperti ini masih dianggap kurang tersampaikannya materi yang diajarkan karena siswa cenderung malas membaca jika medianya berbentuk buku, tidak ada gambar atau animasi yang menarik dilihat. Hal ini sejalan dengan (Miftah, 2014) menjelaskan bahwa peserta belajar kurang antusias dan pasif dalam mengikuti proses belajar mengajar dengan gaya klasikal, masih banyaknya peserta belajar yang senang bermain dan belum terarahkan. Hasil penelitian ini mengkaji berupa penerapan media pembelajaran berbasis software wondershare filmora ini dapat memudahkan proses belajar mengajar siswa SD.

\section{METODE}

Jenis penelitian ini adalah penelitian kualitatif. Pada pendekatan kualitatif penulis ingin menggali atau mencari tahu lebih dalam tentang penerapan media pembelajaran berbasis software wondershare filmora pada mata pelajaran IPA di SD. (Sugiyono, 2007) berpendapat bahwa, metode kualitatif sering disebut metode penelitian naturalistik karena penelitiannya dilakukan pada kondisi yang alamiah. Pendekatan ini digunakan karena data yang diperoleh merupakan data deskriptif yang berupa kata-kata tertulis dan lisan dari narasumber serta berupa perilaku yang diamati.

Teknik pengumpulan data sangat penting agar data yang diperoleh valid dan menghasilkan kesimpulan yang valid. Beberapa bentuk Teknik pengumpulan data yang digunakan dalam pengumpulan data sebagai berikut.

Observasi

Proses pelaksanaan pengumpulan data menggunakan observasi berperan serta (participant observation) dimana peneliti terlibat dengan kegiatan sehari-hari orang yang sedang diamati atau yang digunakan sebagai sumber data penelitian maka dari itu, observasi partisipan ini menghasilkan data yang lebih lengkap, tajam, dan sampai mengetahui pada tingkat makna dari setiap perilaku yang nampak.

Wawancara

Wawancara yang peneliti lakukan adalah wawancara terstruktur, sehingga peneliti terlebih dahulu mempersiapkan instrumen wawancara. Wawancara yang peneliti lakukan ialah wawancara langsung untuk mendapatkan data yang lengkap dan menjaga kevalidan hasil wawancara perlu adanya pencatatan data yang peneliti lakukan dengan menyiapkan smartphone yang berfungsi untuk merekan hasil wawancara. 
Dokumentasi

Dokumentasi pada penelitian ini digunakan sebagai bahan bukti telah meneliti bagaimana penerapan media pembelajaran berbasis Software Wondershare Filmora pada mata pelajaran IPA. Dokumentasi berupa datadata kondisi atau keadaan fisik sekolah, letak sekolah, sarana penunjang pembelajaran, keadaan siswa, media pembelajaran, RPP guru, hasil nilai siswa.

Miles dan Huberman (Sugiyono, 2007) menyatakan bahwa analisis data kualitatif dilakukan secara interaktif dan berlangsung secara terus-menerus sampai tuntas sehingga datanya sudah jenuh. Tahapan aktivitas dalam analisis data yaitu data reduction, data display, dan conclusion drawing/verification.

Reduksi Data

Apabila data sudah terkumpul maka langkah selanjutnya mereduksi yaitu merangkum, membuang hal yang tidak perlu dan mengorganisasikannya sehingga nantinya mudah dilakukan penarikan kesimpulan. Adapun data yang direduksi yaitu data yang diperoleh melalui wawancara yang meliputi media pembelajaran yang digunakan oleh guru kelas VI SD.

\section{Penyajian Data}

Penyajian data didapat dari reduksi data sehingga dalam penyajian ini peneliti telah memahami apa yang terjadi di lapangan khususnya dalam penerapan media pembelajaran IPA berbasis software wondershare filmora materi perkembangbiakan hewan kelas VI SD

Kesimpulan

Setelah data disajikan maka langkah selanjutnya adalah penarikan kesimpulan. Kesimpulan ini berdasar kepada reduksi dan sajian data yang merupakan jawaban atas masalah yang digunakan dalam penelitian. Kesimpulan dalam penelitian kualitatif dapat berupa kata-kata, tulisan, dan tingkah laku sosial dari subjek peneliti.

\section{HASIL DAN PEMBAHASAN}

Penerapan media pembelajaran berbasis Software Wondershare Filmora pada mata pelajaran IPA pada siswa kelas VI SD adalah penerapan media pembelajaran menggunakan bantuan media agar kegiatan belajar mengajar dapat berkembang lebih kreatif dan inovatif. Penerapan media pembelajaran yang digunakan untuk penelitian ini adalah Wondershare Filmora karena mempunyai program yang mudah dirancang dan sederhana dalam hal penggunaan. Sebelumnya, media pembelajaran yang digunakan hanya sebatas power point text dan pembelajaran yang digunakan pada saat ini adalah pembelajaran jarak jauh.

\section{Penerapan Media Pembelajaran Berbasis Software Wondershare Filmora}

Pelaksanaan pembelajaran adalah suatu proses yang diatur sedemikian rupa menurut langkah-langkah yang disusun dalam kurikulum dan rencana pelaksanaan pembelajaran (RPP) serta kurikulum agar pelaksanaan mencapai hasil yang diharapkan. Penerapan media pembelajaran berbasis software wondershare filmora pada mata pelajaran IPA di kelas VI SD adalah penerapan media pembelajaran menggunakan bantuan media agar kegiatan belajar mengajar dapat berkembang lebih kreatif dan inovatif. Penerapan media pembelajaran yang digunakan untuk penelitian ini adalah Wondershare Filmora karena mempunyai program yang mudah dirancang dan sederhana dalam hal penggunaan. Sebelumnya, media pembelajaran yang digunakan oleh guru kelas VI SD yaitu menggunakan power point text untuk memberikan materi dan penugasan tertulis.

Pembuatan video pembelajaran untuk guru juga sangat diperlukan, sekolah dapat memfasilitasi guru-guru dengan melakukan pelatihan pembuatan media pembelajaran menggunakan software wondershare filmora, kemudian media pembelajaran tersebut dapat diupload ke platform youtube sebagai bahan ajar. Pembuatan media pembelajaran diawali dengan merekam kegiatan awal dan kegiatan akhir guru, materi yang disampaikan telah berbentuk video beserta suara guru, setelah itu media pembelajaran siap digunakan. Penerapan media pembelajaran berjalan dengan lancar. Setelah kegiatan penerapan media pembelajaran berbasis software wondershare filmora, kemudian guru kelas memberikan tugas tertulis melalui media WhatsApp. Faktor penghambat dalam menerapkan media pembelajaran berbasis software wondershare filmora adalah keterbatasan guru dalam penggunaan softwarenya, guru kurang menguasai dalam hal pembuatan video seperti masih 
terdapatnya pelafalan kalimat yang kaku maupun suara dan penampilan. Faktor penghambat lainnya yaitu terkendala dengan sinyal sehingga pemutaran media pembelajaran dalam kegiatan belajar mengajar terputus dikarenakan koneksi tidak stabil. Kurangnya pemahaman guru terhadap pembuatan media pembelajaran juga dapat menghambat keberhasilan pelaksanaan pembelajaran daring itu sendiri.

Media pembelajaran mampu menarik perhatian siswa dan memberi fokus terhadap materi. Hal tersebut sejalan dengan pendapat yang dikemukakan oleh (Nazhifah, 2021) media pembelajaran adalah segala bentuk alat fisik yang dirancang secara terencana untuk menyampaikan pesan dan/ atau informasi serta membangun interaksi. Guru dapat memilih media yang paling tepat sesuai dengan karakteristik siswa dan hasil belajar yang diharapkan. Pengunaan media pembelajaran dalam proses belajar diharapkan mampu menumbuhkan semangat belajar peserta didik sehingga menimbulkan interaksi-interaksi baik itu antara peserta didik satu dengan yang lain maupun antara peserta didik dan guru. (Eliwatis \& Sabarullah, 2021) mengemukakan bahwa salah satu media pembelajaran yang cocok digunakan pada saat penerapan proses pembelajaran adalah aplikasi wondershare filmora adapun kelebihan yang dimiliki wondershare filmora yaitu aplikasi yang ringan, pengoperasiannya sangat mudah, editing cepat, dan banyak efek yang tersedia. Penerapan media pembelajaran menggunakan software wondershare filmora, dapat meningkatkan hasil belajar peserta didik kelas VI SD dibuktikan dengan adanya ratarata keseluruhan yang telah mencapai KKM yang telah ditentukan. Penerapan media pembelajaran berbasis software wondershare filmora mata pelajaran IPA kelas VI SD telah digunakan pada kegiatan belajar mengajar (KBM) berlangsung. Penggunaan beberapa alat pembelajaran telah diterapkan dinilai dapat membantu mewujudkan suatu pembelajaran yang efektif dan efisien. Selain itu, secara tidak langsung dapat membantu dalam hal penyajian materi dengan maksimal melalui penggunaan software wondershare filmora. Hasil penelitian tersebut dapat disimpulkan bahwa penerapan media pembelajaran pada kelas VI materi perkembangbiakan hewan berbasis software wondershare filmora di SD telah berjalan dengan baik melalui teknologi software dan hardware yang digunakan untuk menghubungkan keterampilan, pengetahuan, serta sikap.

\section{Dampak Penerapan Media Pembelajaran Berbasis Software Wondershare Filmora}

Penerapan media pembelajaran berbasis software wondershare filmora pada mata pelajaran IPA pada siswa kelas VI SD merupakan penggunaan media pembelajaran berbentuk video yang dibantu oleh platform penyedia video streaming dalam jumlah banyak seperti zoom. Penerapan ini disampaikan oleh guru wali kelas sedangkan kesiapan alat dan pengeditan media dibantu oleh peneliti. Penyampaian materi perkembangbiakan hewan dengan penerapan media software wondershare filmora menjadikan peserta didik lebih paham dan mudah mengerti pembagian hewan ovipar, vivipar, ovovivipar sesuai dengan fungsi media itu sendiri. Dalam proses pelaksanaannya, respon siswa sangat baik dan memperhatikan materi dari awal hingga akhir pembelajaran sehingga nilai yang didapat siswa lebih baik daripada nilai sebelumnya. Hal tersebut terlihat pada peningkatan nilai hasil belajar siswa yang telah mencapai KKM. Berikut nilai hasil belajar siswa kelas VI pada mata pelajaran IPA, dapat dilihat pada tabel di bawah ini.

Tabel 1. Nilai Hasil Belajar Siswa Mata Pelajaran IPA

\begin{tabular}{ccccc}
\hline No & $\begin{array}{c}\text { Nilai Sebelum } \\
\text { Penerapan Media }\end{array}$ & $\begin{array}{c}\text { Nilai Setelah } \\
\text { Penerapan Media }\end{array}$ & KKM & Keterangan \\
\hline 1 & 65 & 76 & 76 & Mencapai KKM \\
2 & 50 & 80 & 76 & Mencapai KKM \\
3 & 85 & 100 & 76 & Mencapai KKM \\
4 & 65 & 100 & 76 & Mencapai KKM \\
5 & 75 & 80 & 76 & Mencapai KKM \\
6 & 80 & 100 & 76 & Mencapai KKM \\
7 & 65 & 80 & 76 & Mencapai KKM \\
Nilai Rata-Rata & 60 & 77,15 & 76 & \\
\hline
\end{tabular}

Adapun dampak siswa yang sangat signifikan yaitu fokus siswa sehingga bisa menjawab soal dari guru dengan benar dan implementasi media ini tidak membuat siswa jenuh dalam proses pembelajaran seperti pembelajaran sebelumnya yang tidak menggunakan media software wondershare filmora. 
Software Wondershare Filmora sebagai bentuk media pembelajaran yang diterapkan pada kegiatan belajar mengajar secara daring dikarenakan media tersebut mampu membentuk siswa yang unggul dalam ilmu pengetahuan dan teknologi. Selan itu, penerapan media pembelajaran dengan software sebagai gambaran untuk meningkatkan kualitas Pendidikan pada kehidupan di masa mendatang. Berlangsungnya penerapan media pembelajaran software wondershare filmora sebagai sarana yang tidak hanya terfokus pada pembelajaran, melainkan menumbuhkan inovasi serta kreativitas antara guru dan siswa seperti halnya pada pembuatan media ajarnya. Penerapan tersebut jika dikelola dengan baik maka akan memberikan pengaruh atau dampak positif terhadap peningkatan motivasi dalam pembelajaran IPA hal ini sependapat dengan (Darmawan, 2014) yang menjelaskan bahwa teknologi pendidikan dan pembelajaran dapat mewujudkan suatu ide maupun pemikiran dan prosedur tindakan yang akan dilanjutkan dalam sebuah proses inovasi terhadap pendidikan sehingga mampu melahirkan pemikiran baru yang berkaitan dengan sumber belajar berbasis teori, media, bahkan teknologi.

Dampak yang dihasilkan dalam penerapan media pembelajaran ini adalah fokusnya peserta didik dalam hal mencermati materi sehingga tidak membuat peserta didik kebingungan. Walaupun materi disiarkan melalui zoom tetapi tidak melunturkan semangat siswa untuk belajar dan media pembelajaran juga di upload pada platform youtube sehingga memudahkan siswa untuk belajar agar tidak cepat lupa. Wondershare Filmora ini dapat menampilkan sebuah film atau video yang dapat digunakan dan sesuai dengan kebutuhan, seperti mengaitkan tentang sebuah pembelajaran yang akan diperhatikan kepada siswa dengan memperhatikan nilai dan sikap dalam mengikuti pembelajaran (Ramadhani \& Fajriyah, 2021). Media pembelajaran IPA berbasis software wondershare filmora ini berhasil memudahkan peserta didik dalam kegiatan belajar mengajar. Selain karena medianya berbentuk video, juga dalam komposisi warna, teks, gambar membuat peserta didik jadi tidak jenuh dan senang menjalankan kegiatan pembelajaran tersebut. Hasil data lapangan menerangkan bahwa ketika penyampaian materi perkembangbiakan hewan dengan penerapan media dengan menggunakan video yang dibantu oleh software wondershare filmora peserta didik lebih paham dan mudah mengerti pembagian hewan ovipar, vivipar, ovovivipar sesuai dengan fungsi media itu sendiri. Penerapan media pembelajaran berbasis software wondershare filmora memberikan dampak baik dalam aspek pendidikan, karena materi yang diberikan tidak secara garis besarnya saja melainkan lebih lengkap karena mengutip dari beberapa sumber. Hasil data lapangan menerangkan bahwa ketika penyampaian materi IPA dengan penerapan media pembelajaran berbasis Software Wondershare Filmora, peserta didik semakin mudah mengerti dan memahami materi yang disampaikan siswa aktif mengikuti proses pembelajaran dari awal hingga akhir dan mengamati dengan fokus, dalam artian lebih baik dari yang sebelumnya. Tidak hanya itu, sebagian besar siswa dapat menjawab pertanyaan dari guru dan menunjukkan rasa percaya dirinya ketika proses pembelajaran berlangsung. Hal tersebut sejalan dengan pendapat (Nyoman et al., 2021) media pembelajaran audiovisual yang dikembangkan memiliki keterbaruan dan membedakannya dari penelitian yang lain adalah penggunaan aplikasinya yaitu menggunakan aplikasi filmora yang mudah digunakan karena fitur di dalamnya lengkap dan jelas.

Hal terpenting yang terdapat pada dampak implementasi media ini adalah keberhasilan peserta didik dalam suatu pembelajaran tidak hanya dipengaruhi oleh sarana dan prasarana, melainkan peran guru dan siswa sebagai faktor utama untuk mencapai keefektifan dalam proses belajar mengajar. Media pembelajaran yang diterapkan oleh guru kelas VI SD Negeri 006 dinilai efektif karena guru menggunakan media pembelajaran berbasis software wondershare filmora dalam bentuk video pembelajaran, penugasan tertulis dan praktik. Terkait hasil penerapan media pembelajaran software wondershare filmora pada mata pelajaran IPA siswa kelas VI SD Negeri 006 Balikpapan menunjukkan feedback yang baik dan dapat dikategorikan berhasil. Berdasarkan hasil penelitian, guru kelas VI lebih menekankan pada tingkat pemahaman siswa pada mata pelajaran IPA agar dapat berpengaruh pada prestasi siswa. Selain itu, keterlibatan software wondershare filmora dalam proses pembelajaran juga dilakukan secara optimal mengingat software wondershare filmora sebagai alat pendukung pembelajaran untuk memberikan pemahaman atau stimulus kepada siswa. Hal tersebut juga didukung oleh (Arsyad, 2013) bahwa pemakaian media pembelajaran dan kegiatan belajar mengajar dapat meningkatkan stimulus, minat, motivasi bahkan membawa pengaruh psikologis terhadap peserta didik.

\section{SIMPULAN}

Berdasarkan hasil penelitian dan pembahasan di atas, dapat ditarik kesimpulan dalam penilitian ini yaitu, penerapan media pembelajaran berbasis software wondershare filmora mata pelajaran IPA pada siswa kelas VI SD memanfaatkan beberapa macam jenis aplikasi seperti whatsapp, zoom, youtube. Guru melakukan penerapan 
media pembelajaran yang berbasis software wondershare filmora dan menyiarkannya melalui aplikasi zoom kemudian juga mengirim media pembelajaran tersebut dalam platform youtube sehingga peserta didik dapat mengulang penjelasan materi. Rencana pelaksanaan pembelajaran menggunakan RPP daring satu lembar tanpa mengurangi isi dari materi tersebut dan sesuai dengan anjuran pemerintah, dan evaluasi yang dilakukan oleh guru menggunakan pemberian soal tertulis yang dikirim melalui aplikasi whatsapp dan dapat dikumpulkan langsung ke sekolah pada jadwal tertentu. Sedangkan hambatan yang terjadi pada kegiatan pembelajaran ini adalah keterbatasan guru dalam penggunaan software, guru kurang menguasai dalam hal pembuatan video seperti masih terdapatnya pelafalan kalimat yang kaku baik dalam suara maupun penampilan. Dampak yang terjadi dalam menerapkan media pembelajaran berbasis software wondershare filmora ini adalah efektif dikarenakan peserta didik lebih tertarik daripada media pembelajaran menggunakan buku biasa, adanya media pembelajaran berbasis software wondershare filmora pada mata pelajaran IPA membuat peserta didik lebih paham dan tidak jenuh dalam kegiatan pembelajaran.

\section{Ucapan Terima Kasih}

Ucapan terima kasih yang besar kami sampaikan kepada Kepala Sekolah SD Negeri 006 Balikpapan yang telah memfasilitasi dan mengizinkan kami untuk melakukan penelitian, kepada kedua pembimbing Ibu Mustamiroh, S.Pd., M.Pd dan Ibu Dra. Sudillah Mangkuwiata, M.Pd yang telah dengan sabar membimbing penulis sampai selesai dan semua pihak yang telah membantu yang tidak dapat penulis tuliskan satu per satu.

\section{Daftar Pustaka}

Arsyad, A. (2013). Media Pembelajaran. Rajagrafindo Persada.

Bouato, Y., Lihawa, F., \& Rusiyah, R. (2020). Pengembangan Media Pembelajaran Berbasis Sparkol Videoscribe Yang Diintegrasikan Dengan Wondershare Filmora Pada Mata Pelajaran Geografi Materi Mitigasi Bencana Alam. Jambura Geo Education Journal, 1(2), 71-79. https://doi.org/10.34312/jgej.v1i2.7131

Darmawan, D. (2014). Inovasi Pendidikan. Remaja Rosdakarya.

Eliwatis, \& Sabarullah. (2021). Pengembangan Video Pembelajaran Pendidikan Agama Islam Berbasis Aplikasi Wondershare Filmora. At-Tarbiyah Al-Mustamirrah: Jurnal Pendidikan Islam, 2(1), 25. https://doi.org/10.31958/atjpi.v2i1.3319

Isroqmi, A. (2015). Pemilihan Software Aplikasi Untuk Pembuatan Media Pembelajaran Interaktif (Studi Kasus : Aplikasi PowerPoint). Jurnal Dosen Universitas PGRI Palembang., 1317-1336.

Kurniawan, D. (2020). Edit Video Youtube dengan Filmora. Gramedia.

Lestari, S. (2018). Peran Teknologi dalam Pendidikan di Era Globalisasi. Edureligia; Jurnal Pendidikan Agama Islam, 2(2), 94-100. https://doi.org/10.33650/edureligia.v2i2.459

Miftah, M. (2014). Pemanfaatan Media Pembelajaran Untuk Peningkatan Kualitas Belajar Siswa. Jurnal Kwangsan, 2(1), 1. https://doi.org/10.31800/jurnalkwangsan.v2i1.11

Nazhifah, N. (2021). Fakultas keguruan dan ilmu pendidikan universitas sriwijaya 20210.

Nurpavitra, D., \& Sudjanarti, D. (2019). Pembuatan Iklan Video di Sosial Media Menggunakan Aplikasi Wondershare Filmora untuk Meningkatkan Penjualan pada Toki Food. Jurnal Aplikasi Bisnis, Volume 5 N.

Nyoman, L., Kusuma, P., Astawan, I. G., \& Suarjana, I. M. (2021). Belajar Ekosistem dengan Media Pembelajaran Audiovisual Berbasis Aplikasi Filmora untuk Siswa Sekolah Dasar. 4(3), 493-501.

Ramadhani, L., \& Fajriyah, K. (2021). Pengembangan Media Video MAJUDDA (Tema Wujud Benda) Berbasis Model Pembelajaran. 17(3), 29-39.

Rosyid, M. Z. (2019). Ragam Media Pembelajaran. Literasi Nusantara Abadi.

sugiyono. (2017). Pengembangan Video Pembelajaran Berbantu Wondershare Filmora Berbasis Kearifan Lokal Terhadap Keterampilan Kompetensi Guru dan Menulis Deskripsi Siswa Kelas 3metode. In Prosiding Seminar Nasional Pendidikan. 
Sugiyono. (2007). Metode Penelitian Kuantitatif dan Kualitatif dan REDD. Alfabeta.

Tea, F. G. (2019). Pengembangan Video Pembelajaran Filmora Pada Mata Pelajaran Sejarah Kelas X Sekolah Menengah Atas Negeri 3 Palembang. Skripsi.

Wahid, A. (2018). Pentingnya Media Pembelajaran dalam Meningkatkan Prestasi Belajar. Istiqra, 5(2), 1-11. 